\title{
THE EFFECT OF INCOME WITH HOUSEHOLD CONSUMPTION ON THE WELFARE OF DODOL POTATO BUSINESS ASSESSED FROM ISLAMIC ECONOMIC CONCEPT
}

\author{
Cendra ${ }^{1}$, Muhammad Fauzi ${ }^{2}$, Arzam $^{3}$, Aidil Novia ${ }^{4}$, Hulwati $^{5}$, Yuserizal Bustami ${ }^{6}$, Dafiar \\ Syarif 7 , Mursal ${ }^{8}$ \\ Postgraduate Students UIN Imam Bonjol Padang ${ }^{1}$, IAIN Kerinci ${ }^{2,3}$, UIN Imam Bonjol \\ Padang ${ }^{4,5}$, IAIN Kerinci $i^{6,7,8}$ \\ pratama.chendra@gmail.com ${ }^{1}$, mf0093391@gmail.com ${ }^{2}$, arzamzain46@gmail.com ${ }^{3}$, \\ aidilnovia@uinib.ac.id ${ }^{4}$, hulwati@uinib.ac.id ${ }^{5}$ yuserizal888@gmail.com $^{6}$. \\ dafiarsyarif24@gmail.com ${ }^{7}$, mursalbesty@gmail.com ${ }^{8}$
}

\begin{abstract}
The purposed of this study was to analyze the influence between income and housebold consumption on the welfare of dodol potatoes business in Lubuk Nagodang Village, Siulak Subdistrict, Kerinci regency. This study was assessing the welfare of dodol business in Islamic economic concepts and indicators. Field research with quantitative-qualitative (Mixed Method) as the method and approach used in this research. The research data was sourced from primary data, using multiple linear regression equations as a data analysis tool. This study was shown that the income partially has a significant effect on the welfare of potatoes dodol business that assessed from the Islamic economic concept. Then, household consumption partially has a significant effect on the welfare of potatoes dodol business assessed from the concept of Islamic economics. Besides, the income with household consumption simultaneously has a significant effect on the welfare of potatoes dodol business assessed from the concept of Islamic economics with a significance value of 0.000 $<0.05$, and both variables contribute 69.2\% together, while the remaining $30,8 \%$ influenced or explained by other factors not discussed in this study.
\end{abstract}

Keywords: Income, Consumption, Welfare, Islamic Economy

\section{Introduction}

Kerinci Regency, Jambi Province is one of the fertile agrarian areas and produces a variety of agricultural and plantation sector products. Potato tubers are most widely grown by rural communities in Kab. Kerinci, which directly delivers suppliers of market needs, both inside and outside daraeh. BPS recorded in 2018 approximately 1,009,720 quintets of potato crops by garden farmers in the village (BPS, Kabupaten Kerinci Dalam Angka 2018) 
The amount of potato harvest above, the unrelenting rural community Of Kerinci gave rise to ideas and innovations by opening a leisure business, namely the dodol kentang business. One of the villages in Kab. Kerinci that opened the free dodol potato business, namely lubuk Nagodang village Siulak Subdistrict.

J.A (Kades Lubuk Nagodang) revealed that;

"Usaha dodol kentang merupakan usaha milik keluarga rumah tangga. Para pelaku usaha dodol kentang ini, mengolah kentang menjadi suatu produk makanan yang siap saji dan diperjual belikan, dengan dibantu alat penglohanya berupa mesin dan alat sejenisnya. Selanjutnya, pelaku usaha yang mengelola usaha dodol kentang memiliki profesi yang berbeda, ada yang berkerja sebagai petani, ibu rumah tangga, dan Pegawai Negeri Sipil (PNS). Selain itu, dilihat dari perkembangan usahanya menjadi salah sumber penghasilan dan penghasilan itu pun bisa dipegunakan mereka untuk membeli kebutuban bidup merka seahari-har" (Interview, 10 January 2020).

Based on the expression of Mr. Kades above, dodol potato business is an individual business between families. Interestingly, this business is not only in demand by families who work as farmers, housewives, even some whose professions as civil servants. Furthermore, the businesses it manages actually contribute more to their income and consumption outaga.

Thus, it is clear that the dodol business actually brings a more positive impact, especially an increase in household income and consumption. So when families open up business opportunities, which directly leads to an increase in their own income and consumption (Rahman \& Khan, 2013; Syathori, 2016).

Significantly, increasing income is certainly in the fulfillment of needs (consumption) is also easily obtained so that directly achieved the welfare of individuals and households themselves (Samuelson \& Nordaus, 2004; Sukirno, 2000, 2005).

From there it seems clear that between income and consumption is inseparable, because it becomes a simple variable that determines well-being, both economically conventionally and Islamicly. Nevertheless, it is very important to remember that the concept of conventional economics and Islamic economy differs from the appraiser side. Economically conventional, the concept and income indakor with consumption is seen only on the material aspect (world) only (Nelson \& Consoli, 2010; Nicklaus, 2015; Wagle, 2007), as well as the concept and indicator of material aspect welfare (world) is also the main goal in order to achieve the happiness of individuals or households (Pigou, 1932; Todaro, 2006). This is precisely rejected in the concept and indicators in Islam, because Islam offers a balance between material aspects (world) and spiritual (hereafter) so that the in essence happiness (falah) (Al-Ghazali, n.d.; Furqani, 2017; Nawawi, 2013; Nurrohman, 2011; Rahim, 2013; Pusparini, 2015; P3EI, 2015; Syathori, 2016; Khan, 1994).

When looking at the business dodol potato megambarkan that the level of keseajhteraanya already included in the prosperous family II, which in general they can 
already meet material and non-material needs, such as food, clothing, boards, health, education, employment (Dokumentasi Desa Lubuk Nagodang, n.d.). In addition, they have also fulfilled the needs of the development of spiritual improvement (religion), such as praying five fardhu five times a day overnight in congregation, saving, following religious activities, and saving money, as well as blessings, faking and others as such.

D. P (Pengurus Masjid Desa Lubuk Nagodang) revealed that;

"Hampir setiap minggu terutama di hari jum'at infaq yang mereka terima tidak pernab kurang dari Rp. 500.000 dari masyarakat yang berusah dodol, tanpa terkecuali sebagian masyarakat desa yang tidak berusa dodol pun juga mmaberikan infaq"(Interview, 12 January 2020).

From a number of data described above, then came the question to be studied in this study, namely; first how the influence of income on the welfare of the family on potato dodol businesses in lubuk nagodang village is judged from the concept of Islamic economy? Secondly how does the influence of household consumption on the welfare of the family on potato dodol businesses in Lubuk Nagodang village from the concept of Islamic economics? Third How is the influence of household income and consumption on the welfare of the family on potato dodol businesses in Lubuk Nagodang village is judged from the concept of Islamic economy?.

This study aims to assess the influence of income on the welfare of families in potato dodol businesses in Lubuk Nagodang village is assessed from the concept of Islamic economics. Slanjutnya also analyzed household consumption of family welfare in potato dodol businesses in Lubuk Nagodang village assessed from the concept of Islamic economy. And also conducting an analysis of the influence of income together with household consumption on the welfare of the family in the potato dodol business in lubuk nagodang village is assessed from the concept of Islamic economy

\section{Review of Related Literature}

In line with consumption income, where conventional economic concepts and indicators look only at material (worldly) aspects solely in the fulfillment of wants and needs (Nelson \& Consoli, 2010; Nicklaus, 2015; Wagle, 2007). Similarly, conventional economic welfare concepts and indicators do not allude to the spiritual aspect (hereafter), offering more on the material aspect (the world) alone so that happiness is created for them (Pigou, 1932; Todaro, 2006).

Income is always associated with income earned by individuals or families from work and/or results from production, either in the form of money or services for a certain period (daily, weekly, monthly, and yearly) ( BPS), n.d.-a; Sukirno, 2000; 2005;). eanwhile, consumption is the expenditure of individuals or households in purchasing goods and services that can provide satisfaction (Utility) to various types fulfillment of needs. And consomsi also often interpreted the behavior of individuals or households in maximizing utility utilizing economic functions on objects or services (Samuelson \& Nordaus, 2004; Sukirno, 2005). 
In Islamic economics, the material asepk (world) and spiritual (hereafter) must be balanced and/or holistic. Concepts and indicators of income and consumption must be clear origin, because each fulfillment of the wishes and needs of individuals or households in terms of income (seeking sustenance) and expenditure (consumption) contains value so as to deliver happiness (welfare) in essence (falab) (Al-Ghazali, n.d.; Furqani, 2017; Nawawi, 2013; Nurrohman, 2011; Rahim, 2013, Septiana, 2015). This is the purpose of Islam upholding the purpose of sayariat (Maqasid Syariab) (Pusparini, 2015). The balance between the world and the hereafter so as to promote the welfare(falah)that is essential for indivisu or household (P3EI, 2015; Syathori, 2016; Susanto \& Manara, 2017). Akram Khan explains the concept of falab which in general has 3 dimensions and has wider implications covering individuals (micro) and collective (macro). Among its dimensions is the survival of life; social and political survival; freedom of desire; and strength and self-esteem; (Khan, 1994).

In the modern context, the concept of welfare is described as a condition in which one can meet the material (economic) and non-material (social) aspects, as well as alluded to the spiritual aspects as described in (Law No. 11 of 2009 on Social Welfare, n.d.) - I'm not If this need is achieved for individuals and communities, then man will have complete happiness (UU No. 11 tahun 2009 tentang Kesejahteraan Sosial, n.d.). If this need is achieved for individuals and communities, then man will have complete happiness (AlGhazali, n.d.; Badawi, 1982). It is also supported by Rahim (2013), Nawawi (2013), Nurrohman (2011) that pressure on the material aspect and spiritual aspect is a characteristic of the Islamic economic system. Spritual and materil have become so sustainable with each other that they may act as a source of strength and together for prosperity.

\section{Study Method}

This research is a field research (Field Research) conducted in lubuk Nagodang Village Kec. Siulak Kab. Kerinci (Yusuf, 2005). This research is a quantitative-qualitative combination (Mix Method), with the Strategy Mix Method used is the Concurrent Mixed Methodstrategy, which collects quantitative data and qualitative data at the same time at the research stage, then compares between quantitative data and qualitative data to find out differences or combinations (Iskandar, 2008; Sugiyono, 2017). The population and samples are focused on potato dodol businesses as many as 66 people. The research uses primary data sources in the form of questionnaires distributed to businesses that are compiled on a likert scale, and also accompanied by observations and interviews (Iskandar, 2008; Tika, 2006). The collected data was analyzed using multiple linear regressions (Sugiyono, 2014) and the analyzing process was assisted by SPSS-23.

In this study, there were 3 (three) research variables, 2 independent variables each, namely income (X1) and household consumption (X2). As well as one dependent variable, namely; welfare of business actors is assessed in the concept of Islamic economy $(Y)$. 


\section{Results and Discussion}

\section{Data Analysis Testing}

\section{Multiple Linear Regression Analysis Testing}

Table 1

Multiple Linear Regression Test Results

\begin{tabular}{|c|c|c|c|c|c|c|}
\hline \multicolumn{7}{|c|}{ Coefficients $^{a}$} \\
\hline & & \multicolumn{2}{|c|}{$\begin{array}{l}\text { Unstandardized } \\
\text { Coefficients }\end{array}$} & \multirow{2}{*}{$\begin{array}{c}\text { Standardized } \\
\text { Coefficients }\end{array}$} & \multirow[b]{2}{*}{$\mathbf{T}$} & \multirow[b]{2}{*}{ Sig. } \\
\hline \multicolumn{2}{|c|}{ Model } & B & Std. Error & & & \\
\hline \multirow[t]{3}{*}{1} & (Constant) & 7,516 & 2,361 & & 3,184 & ,002 \\
\hline & Pendapatan & ,954 & ,201 & ,690 & 4,754 &, 000 \\
\hline & $\begin{array}{l}\text { Konsumsi Rumah } \\
\text { Tangga }\end{array}$ & ,591 & ,080 & ,164 & 4,129 &, 026 \\
\hline
\end{tabular}

Source: Primary Data Processed SPSS-23

\section{Partial Testing (T Test)}

The results of the test on the effect of income (X1) with household consumption (X2) on the welfare of potato dodol businesses are assessed from the concept of Islamic economy $(\mathrm{Y})$ can be seen in table 2 below:

Table 2

The Result T

\begin{tabular}{|c|c|c|c|c|c|c|}
\hline \multicolumn{7}{|c|}{ Coefficients $^{a}$} \\
\hline & & \multicolumn{2}{|c|}{$\begin{array}{l}\text { Unstandardized } \\
\text { Coefficients }\end{array}$} & \multirow{2}{*}{$\begin{array}{c}\text { Standardized } \\
\text { Coefficients }\end{array}$} & \multirow[b]{2}{*}{$\mathbf{T}$} & \multirow[b]{2}{*}{ Sig. } \\
\hline \multicolumn{2}{|c|}{ Model } & B & Std. Error & & & \\
\hline \multirow[t]{3}{*}{1} & (Constant) & 7,516 & 2,361 & & 3,184 & ,002 \\
\hline & Pendapatan & ,954 & ,201 & 690 & 4,754 & ,000 \\
\hline & $\begin{array}{l}\text { Konsumsi Rumah } \\
\text { Tangga }\end{array}$ & ,891 & ,180 &, 564 & 4,129 & ,000 \\
\hline
\end{tabular}

Source: Primary Data Processed SPSS-23

The results of the test on the effect of income (X1) with household consumption (X2) on the welfare of potato dodol businesses are assessed from the concept of Islamic economy $(\mathrm{Y})$ can be seen in table 3 below:

Table 3

The Result R2

\begin{tabular}{|l|l|l|c|c|}
\hline \multicolumn{9}{|c|}{ Model Summary } \\
\hline Model & R & R Square & $\begin{array}{c}\text { Adjusted R } \\
\text { Square }\end{array}$ & $\begin{array}{c}\text { Std. Error of the } \\
\text { Estimate }\end{array}$ \\
\hline
\end{tabular}




\begin{tabular}{|c|c|c|c|c|}
\hline 1 &, $838^{a}$ &, 702 &, 692 & 2,077 \\
\hline \multicolumn{2}{|l|}{ a. Predictors: (Constant), Income and Household Consumption } \\
\hline
\end{tabular}

Source: Primary Data Processed SPSS-23

In table 3 above it is obtained that the Adjusted R Square (R2) value is 0.692. This means that the establishment (X1) with household consumption (X2) contributes jointly to the welfare of dodol businesses assessed from the Islamic economic concept (Y) of $69.2 \%$.

\section{Simultaneous Testing (Test F)}

The results of simultaneous assessment of independent variable (X1) with household consumption (X2) on the welfare of dodol businesses are assessed from the concept of Islamic economy $(\mathrm{Y})$ can be seen in table 4 below:

Table 4.

\section{The Result F}

\begin{tabular}{|c|c|c|c|c|c|c|}
\hline \multicolumn{7}{|c|}{ ANOVA $^{a}$} \\
\hline \multicolumn{2}{|c|}{ Model } & Sum of Squares & Df & Mean Square & $\mathbf{F}$ & Sig. \\
\hline \multirow[t]{3}{*}{1} & Regression & 638,911 & 2 & 319,455 & 4,070 &, $000^{\mathrm{b}}$ \\
\hline & Residual & 271,711 & 63 & 4,313 & & \\
\hline & Total & 910,621 & 65 & & & \\
\hline \multicolumn{7}{|c|}{ a. Dependent Variable: Welfare Dodol Potato Business Assessed From Islamic................ } \\
\hline \multicolumn{7}{|c|}{ b. Predictors: (Constant), Income and Household Consumption } \\
\hline
\end{tabular}

Source: Primary Data Processed SPSS-23

In table 4 above shows that simultaneously income (X1) with household consumption (X2) influenced on the welfare of dodol businesses assessed from the concept of Islamic economy $(\mathrm{Y})$, with a sig value of $0.000<0.05$ and an $\mathrm{f}$-count value of 4,070 $>3.14$. From this, it can be concluded that there is an influence of income with simultaneous household consumption on the welfare of businesses dodol potato assessed from the concept of Islamic economy.

\section{Analysis}

The Effect of Income (X2) on the Welfare of Dodol Potato Business Assessed From Islamic Economy Concept (Y)

The results of the analysis test showed that income (X1) has a significant effect on the welfare of businesses dodol potato is assessed in the concept of Islamic economy $(\mathrm{Y})$. This is evidenced by the significance value of $0.000<0.05$. Furthermore, the regression equation obtained $\mathrm{Y}=7,516+0.954 \mathrm{X} 1$, meaning that each increase of $1 \%$ income then leads to an increase of 0.954 welfare of dodol businesses assessed from the concept of Islamic economy at constant 7,516. In short, the income (X1) has a significant effect on the welfare of dodol businesses assessed from the concept of Islamic economy (Y).

The findings show that income is becoming very urgent in improving welfare. Because of the increasing income of potato dodol businesses, the higher their welfare. 
The results of the study are in line with the opinion of U. R. Wagle that in economic theory a person's income is measured by the amount of money he receives, in relation to income and welfare is not only measured from the economy alone, but will be the adequacy of income that a person has in calculating and actualizing for the welfare of his family (Wagle, 2007). Similarly revealed by Sukirno, (2000; 2005;), Rahman \& Khan, (2013).

Islamicly, income associated with well-being has a strong correlation. In this context, income is often associated with means of halal sustenance. With the sustenance obtained so as to achieve human needs (welfare). As Allah SWT has given orders to his servants to try or seek sustenance (income). Seek as much sustenance and guaranteed halal with the way that is guided by Allah SWT (See the word of Allah SW'T in the Qur'an in surah alJuma'ah verse 10; and surah al-Mulk verse 15).

The business actors dodol potatoes looking for sustenance (income) in a way that has been recommended by Allah SWT. They do business by selling their produce. This the author sees during observation, where they have done their business in the direction suggested by Islam. One example is in pricing. Dodol businesses should not sell dodolnya at the price made at will, but must sell at a predetermined price. This is to avoid the monopoly practices that might happen between them.

In addition, the businesses dodol potatoes are also very concerned about the cleanliness of their workplace, for them if their workplace is not clean it will have an impact on the production they make. Furthermore, they also use good ingredients in the manufacturing process and also always use gloves in every process of making potato dodol. This is all they do to maintain their own health and the health of their consumers otherwise the produce they make can be unhealthy to consume. From this explanation, it is claimed that the businesses dodol potato has been in accordance with the concept of seeking sustenance in Islam.

It was confirmed by N. D in an interview with researchers that:

"Besar-kecil penghasilan yang kami terima berdasarkan jumlah produksi yang kami lakukan, semakin banyak kami memproduksi maka semakin banyak keuntungan yang kami peroleh. Biasanya dalam sehari kami bisa menjual 50 sampai 100 kotak perhari diluar dari pengiriman keluar daerah yang rutin kami lakukan" (Interview, 25 March 2020).

D. S also reveals that;

"Hampir setiap hari saya memproduksi dodol dan dibantu oleh beberapa karyawan saya. Dimana penghasilan kami ini adalah hasil dari produksi dodol yang kami lakukan" (Iterview, 15 March 2020).

Furthermore, it is also revealed by M.R:

"sumber utama pendapan kami adalah dari hasil penjualan dodol yang kami terima. Berapapun penghasilan yang saya peroleb setiap barinya, insya Allab saya selalu 
mensyukurinya. Karena keberkahan yang sesunggubnya bukan terletak pada seberapa besar keuntungan yang diperoleb tetapi seberapa kita bisa mensyukuri pemberian yang dititipkan oleh tuban untuk kita" (Interview, 20 March 2020).

Based on the results of the interview, it can be seen that the source of income of potato dodol businesses comes from the sale of potato dodol and wages received from the manufacture of potato dodol. The amount of income they earn depends on the number of dodol they manage to sell to consumers.

Looking at a number of uarain above, it is clear that dodol potato businesses have prospered both economically conventionally and in the Islamic economy, starting from the way they work unwilling to do actions that can harm consumers so that the source of income is guaranteed halal.

\section{Effect of Household Consumption (X2) on the Welfare of Dodol Potato Business} Assessed From Islamic Economy Concept (Y)

The results of the analysis test showed that household consumption (X2) has a significant effect on the welfare of businesses dodol potato assessed in the concept of Islamic economy (Y). This is evidenced by the significance value of $0.000<$ 0.05. Furthermore, the regression equation obtained $\mathrm{Y}=7,516+0.591 \mathrm{X} 2$, meaning that every increase of $1 \%$ in household consumption then leads to an increase of 0.591 welfare dodol businesses assessed from the concept of Islamic economy at constant 7,516. In short, household consumption (X2) has a significant effect on the welfare of dodol businesses assessed from the concept of Islamic economy (Y).

The findings show that household consumption of welfare is very large and falls into the high category. The higher the household consumption of potato dodol businesses, the higher their well-being.

According to Samuelson \& Nordaus (2004), household consumption can be seen as a form of expenditure in making purchases of goods and services that can provide satisfaction with the fulfillment of needs. In line with the opinion of Nelson \& Consoli (2010) stated that consumption describes the level of prosperity of a person or society, with consideration if the higher one's consumption then they will be perceived prosperous while on the contrary then they will be considered poor. In line with this opinion Nicklaus (2015) revealed that household consumption needs are met to the maximum, so it does not close the possibility that the family will also be more prosperous. But on the contrary when the limitations of household budgets received can delay to consume things. In short, household consumption needs are less adequate, the level of family welfare will also be low.

Islamicly, it is also explained that the correlation between consumption and well-being is very strong. In this case, it should be noted that the consumption of Islam is not only seen from the fulfillment of desires and needs of material aspects (the world) only, because Islam also views the fulfillment of desires and needs in the aspect of spiritual (afterlife) (Rahim, 2013). Not that Islam tells people to abandon worldly desires and needs, 
but Islam tells how between the worldly aspect and ukhrawi can maximize their function of taking the pleasure of Allah SWT (See the word of Allah SWT in the Qur'an in surah alQasaas verse 77).

From there, it is clear that the purpose of Islamic consumption is used to seek and realize good, becauseit is a indicator of achieving happiness in the world and the hereafter, which is often interpreted as falah (Nawawi, 2013), which becomes the purpose ofhuman life and must gather all activities in life, including consumption activities so as to deliver "hasanah fi dunn ya wa akbirab" (happiness of the world and the hereafter) (Al-Ghazali, n.d.).

Observations made, seen or assessed economically conventional consumption of businesses dodol potatoes can be sufficient needs and desires so that it is considered prosperous. However, there is still a gap in the concept of Islamic consumption so that its welfare is considered not appropriate in the Islamic economy in Islam. Because of them can not control themselves to buy something that sometimes they do not need. They still like to overdo it in consuming or buying things that are not their basic needs.

Can be seen from the expression L. F one of the following the potato dodol businesses:

"Penghasilan ya saya gunakan untuk. kebutuhan makan sehari-hari keluarga saya, untuk biaya sekolah anak, dan juga bulan lalu saya habis membeli motor baru, yang sbenarnya dirumah sudah ada 2 motor, jadi biar lengkap jadi tiga motor. Selain itu, baru-baru ini saya memasang TV layar yang agak besar di warung dan itu dari hasil penjualan dodoP'(Interview, 22 March 2020).

Meanwhile, it was also revealed by N. W:

"Tentulah yang utama sekali dari penghasilan dodol tidak lain adalah memenubi kebutuhan keluarga saya. Bila kebutuahan saya sudah aman, maka barulah untuk berpindah keinginan memiliki kebutuahn, seperti tahun kemarin niat saya ingin menambah perlengkapan usaha ditempat penjualan dodol saya dengan memasang TV dan seklaigus ada speaker karaoke biar sambil nunggu pembeli bisa sambil karaoke... dan juga niat saya ingin menambah dengan membeli motor baru biar tidak ketinggalan dengan model yang banyak keluar sekarang ini, dan masib banyak yang lain. Dan niat-nait ini, akbirnya terwujud walaupun tidak sepenubnya dari pengahslan usaha dodol karena saya ada sedikit meminjam uang dari bank untuk memnubi kebutuhan itu"'(Interview, 22 March 2020).

From the observations and interviews above, the businesses dodol potatoes in the context of finding a source of sustenance is halal and tayyib. However, in the process of consumption there are some things that are slightly distorted considered islamic, especially excessive in consuming. This is certainly the fulfillment of the needs only for the world alone or controlled by lust alone, and does not appear the value of benefit in achieving the goodness of the world and the hereafter(falab)as explained in the concept above.

Thus, it seems clear that the business actors dodol potatoes in doing consumption to meet the needs of his life still has not reached the point of well-being in the concept of 
Islam falah. So, it can be said that according to the results of the analysis of data and interview results of household consumption relationship to welfare in the concept of Islam falah has a signfikan and positive influence, but in the practice of daily life the businesses dodol potato household consumption they can not be said to achieve prosperity in the concept of Islam falah.

\section{Effect of Income (X1) with Household Consumption (X2) on The Welfare of Dodol Potato Businesses Assessed From Islamic Economic Concept (Y)}

The results of the analysis test showed that income (X1) with household consumption (X2) simultaneously or together has a significant effect on the welfare of businesses dodol potato assessed in the concept of Islamic economy $(\mathrm{Y})$. This is evidenced by the significance value of $0.000<0.05$. Furthermore, the regression equation obtained $\mathrm{Y}=7,516+0,591$ $\mathrm{X} 2+\mathrm{e}$, meaning that any increase in income by 0.954 with a home consumption of 0.591 will lead to improved welfare assessed from the Islamic economic concept of 7,516 . In short, the income (X1) with household consumption (X2) has a significant effect on the welfare of dodol businesses assessed from the concept of Islamic economy (Y). The amount of contribution of $\mathrm{R} 2$ value of household consumption to the welfare of potato dodol businesses is assessed in the islamic economic concept is $69.2 \%$.

The findings above show that the income owned participates in increasing household consumption so as to make the welfare of businesses dodol potato assessed from the concept of Islamic economy. The higher the income earned the higher the household consumption of the dodol potato businesses, the higher their welfare.

The results of this study are similar to that of Dumairy who revealed that a person's income is directly proportional to his consumption. When the income increases then the consumption issued will also increase which then affects the welfare so that it can be said to be able to improve their well-being, then to be able to consume one must have an income (Dumairy, 1996). This was revealed by oleh S. Sukirono (Sukirno, 2000; 2005;), Wagle (2007), Nelson \& Consoli (2010), and Nicklaus (2015) who revealed that income greatly influenced consumption levels. Because if the level of income increases, the ability of the community to buy consumption needs is greater and increasingly demanding good quality so that the level of welfare of the community will also increase.

In Islam regulates all aspects of human life, including the issue of income and household consumption. Islam recommends finding sources of income in a halal way and utilizing the income earned in good ways as well. Islam does not recommend to do excessive coumsi, but rather it is recommended to consume what we need instead of following our desires or lusts.

Back to the results obtained in general, that the businesses dodol potatoes have been looking for income or sustenance in accordance with the recommended by Allah SWT. But in consumption they belong to the consumptive group. They still like to spend what they 
don't really need. In consumption they can not yet consider that whether their groceries real they need or just fulfill their wishes.

Based on the explanation above, it can be concluded that the dodol potato businesses belong to economically prosperous society. But they still have gaps when assessed from the concept of Islamic economic welfare, because there are some businesses dodol in terms of consumption does not pay attention to the consumption they do more heavily to the fulfillment of the needs of the world or controlled by lust.

\section{Conclusion}

Based on the results of the above research shows that partially income has a significant effect on the welfare of businesses dodol assessed from the concept of Islamic economy. The increasing income earned by dodol potato businesse, their welfare can also be increased.

Household consumption has a significant effect on the welfare of dodol businesses. The higher the household consumption of potato dodol businesses, the better their well-being can also be increased. Nevertheless, household consumption of potato dodol businesses is still an oddity, by consuming excess and denying Sharia Maqasid precisely because it is considered not yet prosperous in the concept of Islamic welfare. Therefore, the dodol potato businesses should pay attention to their consumption whether the goods to be purchased is really a necessity or just a gratification of lust. They must pay attention to every item they will buy excessively in order to realize prosperity in the Islamic economy.

Income with simultaneous household consumption has a significant effect on the welfare of businesses dodol assessed from the concept of Islamic economy, with the value of significance for the influence of X1 and X2 simultaneously on $\mathrm{Y}$ is $0.000<0.05$ and the value of f-count $74,070>3.14$. The two variables contributed together by $69.2 \%$, while the remaining 30.8\% were influenced or explained by other factors not discussed in this study. The higher the income earned the higher the household consumption of the dodol potato businesses, the higher their welfare

\section{BIBLIOGRAPHY}

Al-Ghazali, I. (n.d.). Mizan al-Amal bab Ghayat al-Sa'adab wa Maratibuba. Dar al-Kutub.

Badan Pusat Statistik (BPS). (n.d.-a). Badan Pusat Statistik. Retrieved June 29, 2021, from https://www.bps.go.id/

Badan Pusat Statistik (BPS). (n.d.-b). Kabupaten Kerinci Dalam Angka 2018. Retrieved June 29, 2021, from https://kerincikab.bps.go.id/publication/2018/08/16/431cfdc3c20d72464c114b18/ kabupaten-kerinci-dalam-angka-2018.html

Badawi, A. Z. (1982). Mu'jam Mushtalahatu al-U'lum al-Ijtimaiyyah. Maktabah Lubnan. 
Dokumentasi Desa Lubuk Nagodang. (n.d.). Tingkat Perkembangan Desa dan Kelurahan 20152020.

Dumairy. (1996). Perekonomian Indonesia. Erlangga.

Furqani, H. (2017). Consumption and Morality: Principles and Behavioral Framework in Islamic Economics. JKAU: Islamic Economics, 30(Special Issue), 89-102. https:/ / doi.org/10.4197 / Islec. 30-SI.6

Iskandar. (2008). Metode Penelitian Pendidikan Dan Sosial (Kuantitatif \& Kualitatif. Gaung Persada.

Khan, M. A. (1994). An Introduction to Islamic Economics. International Institute of Islamic Thought and Institute of Policy Studies.

Nawawi, I. (2013). Isu-Isu Ekonomi Islam: Kompilasi Pemikiran Filsafat dan Teori Menuju Praktik di Tengah Arus Ekonomi Global. VIV Press.

Nelson, R. R., \& Consoli, D. (2010). An evolutionary theory of household consumption behavior. Journal of Evolutionary Economics, 20(5), 665-687. https://doi.org/10.1007/s00191-010-0171-7

Nicklaus, C. (2015). The effect of household income on household consumption in China Christoph Nicklaus (Issue June 2015) [Lund Unversity]. www.ehl.lu.se

Nurrohman, D. (2011). Memahami Dasar-Dasar Ekonomi Islam. Teras.

P3EI,. (2015). Ekonomi Islam. Raja Grafindo.

Paul Samuelson \& Willian D Nordaus. (2004). Makro Ekonomi (Haris Munandar et al (ed.)). PT. Gelora Aksara Pratama.

Pigou, A. C. (1932). The Economic of Welfare. Mac Millan.

Pusparini, M. D. (2015). Konsep Kesejahteraan Dalam Ekonomi Islam. Islamic Economics Journal, 1(1), 45-59.

Rahim, A. (2013). Ekonomi Islam Prespektif Muhammad SAW. STAIN Jember Press.

Rahman, M. T., \& Khan, H. T. A. (2013). The effectiveness of the microcredit programme in Bangladesh. Local Economy, 28(1), 85-98. https://doi.org/10.1177/0269094212466036

Septiana, A. (2015). Analisis Perilaku Konsumsi Dalam Islam. Dinar: Jurnal Ekonomi \& Keuangan Islam, 1 (2), 1-17. https://doi.org/10.21107/dinar.v2i1.2688

Sugiyono. (2014). Statiska Untuk Penelitian. Alfabeta.

Sugiyono. (2017). Metode Penelitian Bisnis. Alfabeta Bandung.

Sujarweni, V. W. (2015). Statiska Untuk Bisnis dan Ekonomi. Pustaka Baru Press. 
Sukirno, S. (2000). Mikro Ekonomi Modern: Perkembangan Pemikiran dari Klasik Sampai Keynesian Baru. Raja Grafindo.

Sukirno, S. (2005). Mikro Ekonomi Teori Pengantar. Rajagrafindo Persada

Susanto, B. P. \& A. S. Manara. (2017). Sistem Ekonomi Islam: Keseimbangan Dalam Pembangunan dan Kesejahteraan Umat. Dinar: Jurnal Ekonomi \& Keuangan Islam, 4 (1), 1-23. https://doi.org/10.21107/dinar.v4i1.5065

Syathori, A. (2016). Konsep Welfare-Economic: Antara Etika Bisnis Islam Dan Protestan. RIS ALAH; Jurnal Pendidikan Dan Studi Islam, 1(1), 78-93.

Tika, M. P. (2006). Metodologi Riset Bisnis. Bumi Aksara.

Todaro, M. P. \& S. C. S. (2006). Economic Development (11th Editi). Pearson Addison Wesley.

Undang-Undang Republik Indonesia Nomor 11 Tahun 2009 Tentang Kesejahteraan Sosial.

Wagle, U. R. (2007). Poverty in Kathmandu: What do subjective and objective economic welfare concepts suggest? J Econ Inequal, 5, 73-95. https://doi.org/10.1007/s10888006-9026-8

Yusuf, A. M. (2005). Metodologi Penelitian: Dasar-Dasar Penyelidikan Ilmiah. UNP Press. 